Provided for non-commercial research and education use. Not for reproduction, distribution or commercial use.

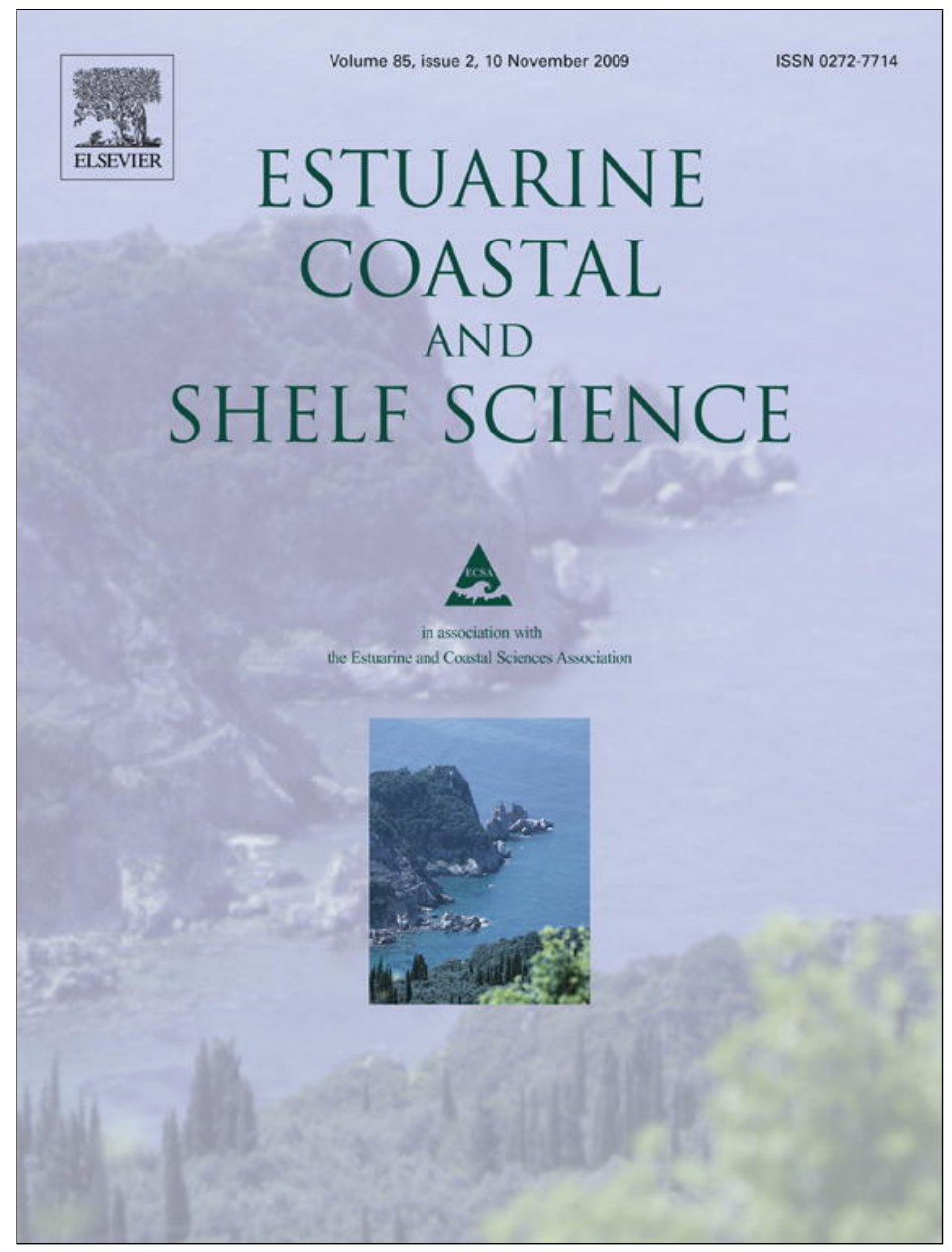

This article appeared in a journal published by Elsevier. The attached copy is furnished to the author for internal non-commercial research and education use, including for instruction at the authors institution and sharing with colleagues.

Other uses, including reproduction and distribution, or selling or licensing copies, or posting to personal, institutional or third party websites are prohibited.

In most cases authors are permitted to post their version of the article (e.g. in Word or Tex form) to their personal website or institutional repository. Authors requiring further information regarding Elsevier's archiving and manuscript policies are encouraged to visit:

http://www.elsevier.com/copyright 


\title{
Biodiversity patterns of free-living marine nematodes in a tropical bay: Cienfuegos, Caribbean Sea
}

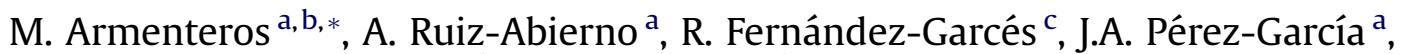 \\ L. Díaz-Asencio ${ }^{c}, M$. Vincx ${ }^{b}$, W. Decraemer ${ }^{d, e}$ \\ ${ }^{a}$ Centro de Investigaciones Marinas, Universidad de La Habana, 16 \# 114, CP 11300, Playa, Ciudad Habana, Cuba \\ ${ }^{\mathrm{b}}$ Marine Biology Section, Department of Biology, Ghent University, Krijgslaan 281 S8, $B 9000$ Ghent, Belgium \\ ${ }^{c}$ Centro de Estudios Ambientales de Cienfuegos, Ministerio de Ciencia, Tecnología y Medio Ambiente, Ciudad Nuclear, Cienfuegos, Cuba \\ ${ }^{\mathrm{d}}$ Department of Invertebrates, Royal Belgian Institute of Natural Sciences, Vautierstraat 29, B1000 Brussels, Belgium \\ ${ }^{\mathrm{e}}$ Nematology Section, Department of Biology, Ghent University, Ledeganckstraat 35, B9000 Ghent, Belgium
}

\section{A R T I C L E I N F O}

\section{Article history:}

Received 6 February 2009

Accepted 7 August 2009

Available online 12 August 2009

\section{Keywords:}

nematodes

meiobenthos

tropical environment

marine ecology

species diversity

Caribbean Sea

\begin{abstract}
A B S T R A C T
Spatial and temporal biodiversity patterns of free-living marine nematodes were studied in Cienfuegos Bay, a tropical semi-enclosed basin in the Caribbean Sea. Taxonomic (to species level) and functional (biological trait) approaches were applied for describing the assemblage structure and relating it to abiotic environment based on a sampling scheme in six subtidal stations and three months. Biological trait approach added relevant information to species pattern regarding relationships between diversity patterns and the abiotic environment. The most common morphotypes were deposit feeding nematodes, with colonising abilities of 2-3 (in a scale from 1 to 5), tail conical cylindrical or filiforme and body slender; and their abundance were correlated with depth, organic matter and silt/clay fraction. In spite of a high turnover of species, functional diversity of assemblages did not change notably in space and time. A result probably due to sampling of the habitat pool of species and to low heterogeneity of the studied muddy bottoms. Chemical pollution (organic enrichment and heavy metals) and hydrodynamic regime possibly drove the biodiversity patterns. Spatial distribution of assemblages support the existence of two well differentiated basins inside the bay, the northern basin more polluted than the southern one. The low hydrodynamic regime would determine a poor dispersion of nematodes resulting in high spatial variance in the assemblage structure; and also the associated hypoxic conditions and pollutants in sediments can explain the dominance of tolerant nematode species such as Daptonema oxycerca, Sabatieria pulchra, Terschellingia gourbaultae, and Terschellingia longicaudata. A comparison of spatialtemporal patterns of biodiversity between Cienfuegos Bay and other semi-enclosed bays in temperate regions suggests several similarities: nematode assemblages are strongly influenced by anthropogenic disturbance, temporal trends are weak or overridden by spatial ones, and few cosmopolitan genera/ species tolerant to pollution and hypoxic conditions are dominant.
\end{abstract}

(c) 2009 Elsevier Ltd. All rights reserved.

\section{Introduction}

The description of distribution patterns is still one of the fundamental starting blocks in the ecology of biological communities (Underwood et al., 2000). Current research is largely based on

\footnotetext{
* Corresponding author. Marine Biology Section, Department of Biology, Ghent University, Krijgslaan 281 S8, B9000 Ghent, Belgium.

E-mail addresses: maickel@cim.uh.cu, maickel.armenteros@ugent.be (M. Armenteros), alexeis@cim.uh.cu (A. Ruiz-Abierno),rfg@gestion.ceac.cu (R. Fernández-Garcés), jose.andres@cim.uh.cu (J.A. Pérez-García), lisbet@ceac.cu (L. DíazAsencio), magda.vincx@ugent.be (M. Vincx), wilfrida.decraemer@naturalscience.be (W. Decraemer).
}

description of assemblages using a taxonomic approach (i.e. species or higher taxa). Analyses of biological traits of species and subsequent creation of functional groups have been introduced in studies focusing on assemblage structure. This relatively new approach allows to obtain insight into the functioning of ecosystems (Norling et al., 2007) and reveals additional relationships in assemblages (Schratzberger et al., 2007). Coupling of taxonomic and functional diversity can be a powerful tool in ecological research, although the relationships between them and with ecosystem functioning is still in an explorative field (Hooper et al., 2005).

Schratzberger et al. (2007) in a comprehensive study on functional diversity and nematode assemblage structure revealed effects of individual species rather than of functional groups. They 
detected a positive relationship between number of species and functional diversity. An additional interesting point addressed in our study is if this relationship is also present at smaller spatial scales (i.e. few kilometres within a bay) and in tropical ecosystems. Further, the relationships between taxonomic and biological trait approaches and environment deserve further exploration using new data.

Very few information on structural aspects of biodiversity has been published for tropical areas regarding free-living nematode assemblages (e.g. Boucher and Gourbault, 1990; Boucher and Lambshead, 1994; Gobin and Warwick, 2006). In addition, the nematode assemblages in semi-enclosed bays have been studied only in temperate regions (e.g. Lampadariou et al., 1997; Liu et al., 2008; Moreno et al., 2008).

Semi-enclosed bays are characterized by relatively shallow waters, low hydrodynamics, and fine and organically enriched sediments; in addition, these habitats are very often affected by anthropogenic disturbances due to urban settlements, harbourage activities and industrial development. The link between anthropogenic and natural processes implies that both should be addressed in surveys of biodiversity patterns in these ecosystems. In the context of relationship pollution-biodiversity, free-living nematodes have been identified as valuable bio-indicators to monitor the anthropogenic impact on biodiversity in coastal ecosystems (Moreno et al., 2008; Vanaverbeke and Vincx, 2008).

Studies in Cienfuegos Bay have been carried out about hydrology (Seisdedo and Muñoz, 2004; Seisdedo, 2006), sediments (Alonso-Hernandez et al., 2006), circulation (Muñoz et al., 2008), and benthic communities (Díaz-Asencio et al., 2009; Pérez-García et al., 2009). They suggest a relatively complex coastal system with high spatial and temporal variance in natural processes and clearly influenced by human activities.

In the present study, we describe the spatial and temporal biodiversity patterns of free-living marine nematode assemblages. The investigation was carried out based on samples from a semienclosed tropical bay (i.e. Cienfuegos Bay, Caribbean Sea) and by using both the taxonomic and biological trait approach. Based on the design of a quantitative study of nematode assemblages in six selected stations inside the bay we intend to answer the following three questions:

(1) Does the biological trait approach provide new interpretable information in comparison to a "classical" taxonomic approach?

(2) Which natural and/or anthropogenic processes determine the biodiversity patterns of free-living nematodes within the Bay?

(3) How different are the biodiversity patterns in a tropical semienclosed bay in comparison with those in similar ecosystems in temperate regions?

\section{Materials and methods}

\subsection{Study site}

Cienfuegos Bay is a semi-closed bay in the Caribbean Sea $\left(22^{\circ} 1^{\prime}\right.$ $\mathrm{N}, 80^{\circ} 2^{\prime} \mathrm{W}$ ) with $90 \mathrm{~km}^{2}$ of area and mean depth of $14 \mathrm{~m}$; it is divided by a submerged ridge of $1.5 \mathrm{~m}$ depth in northern and southern basins (Fig. 1). Most of the subtidal area of the bay is characterized by muddy bottoms with high content of organic matter; although there are other habitats (e.g. seagrass beds, sand flats, mangroves) covering a more limited extension. An extensive previous study on meiofaunal assemblages (to main taxa) in 16 subtidal stations from this bay can be found in Díaz-Asencio et al. (2009).

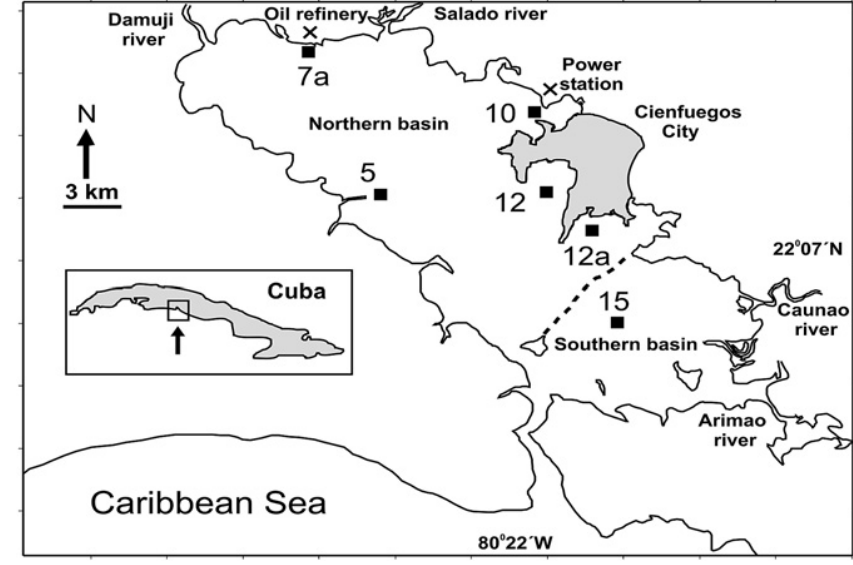

Fig. 1. Study area in Cienfuegos Bay. The six sampling stations are shown. The submerged ridge between northern and southern basins is indicated with a dashed line. The main point pollution sources and rivers are marked.

The circulation in Cienfuegos Bay is driven mainly by tidal currents and to minor extend by winds (Muñoz et al., 2008). There is a seasonal change in water column with salinity stratification and hypoxic conditions in bottom waters of deepest areas $(>10 \mathrm{~m}$ depth) in wet season (May-October). In dry season (NovemberApril) the water column remains mostly mixed and bottom water is oxygenated (Seisdedo and Muñoz, 2004). Further, the rate of sedimentation is seasonally variable, but relatively high (0.47$0.50 \mathrm{~g} \mathrm{~cm}^{-2} \mathrm{y}^{-1}$ ) after Alonso-Hernandez et al., 2006).

The anthropogenic sources of pollution are mostly located in the northern basin (e.g. power plant, refinery of petroleum, Cienfuegos city) with two rivers as main point sources of freshwater and sediments. The southern basin does not have any main source of pollutants along the coast but it also has two main rivers discarding into it (Fig. 1). Eutrophication exists derived from diffuse sewage discharges close to the city, other human settlements and agricultural activities located around the basin (Seisdedo, 2006). A rise of economic activity in the bay, mostly related to refinery of petroleum and derived industries, increases the potential disturbance on the ecosystem by dredging for enhancing of navigation, chemical effluents and accidental spills.

\subsection{Sampling strategy}

Samples were taken in six subtidal stations characterized by fine and organically enriched sediments, four of them close to pollution sources: Cienfuegos City (12 and 12a), oil refinery (7a), and power plant (10) and other two stations relative far from pollution sources i.e. in the northern basin (5) and southern (15). The six stations were located in shallow waters (mean value $9.3 \mathrm{~m}$, range: $3.3-$ $14.3 \mathrm{~m}$ ); the use of GPS device and the small variations in depth in each of the stations among the three months suggest a reasonable accuracy in the sampling of the same site (Appendix 1). The spatial scale of sampling (i.e. among stations) was in the order of tens kilometres (shortest distance between two stations: $6 \mathrm{~km}$; largest: $23 \mathrm{~km}$ ). Three sampling trips were carried out in February, May, and September 2006 ( 6 stations $\times 3$ months $=18$ sampling events). Four cores of sediment for meiofauna $(2.6 \mathrm{~cm}$ inner diameter, surface $5.3 \mathrm{~cm}^{2}$ and $6 \mathrm{~cm}$ deep into the sediment) were carefully taken in each sampling event by SCUBA divers; the four cores were taken at random in proximately a plot of $4 \mathrm{~m} \times 4 \mathrm{~m}$. The cores were immediately fixed in buffered $10 \%$ formalin. From the four cores taken in February, two were immediately divided in four vertical strata $(0-1,1-2,2-4$, and $4-6 \mathrm{~cm})$ in order to investigate the 
vertical distribution of meiofauna inside the sediment. In station 12 , the strata $2-4$ and $4-6 \mathrm{~cm}$ could not be sampled due to the sediment below $2 \mathrm{~cm}$ was relatively coarse (gravel) therefore coring was not so effective and we decided did not include these strata. For the February samples, data belonging to strata from a same core were summed for obtaining the structure assemblage of the whole column of sediment.

Two cores ( $3.0 \mathrm{~cm}$ i.d. PVC pipes) were taken for determination of abiotic factors in each sampling event. One core was used for determination of salinity in the interstitial water using a portable refractometer Atago (1 unit accuracy); salinity is presented in the text as practical salinity units (PSU); the interstitial water was separated from the sediment by centrifugation. The other core was immediately frozen for determination of the content of silt + clay, and concentrations of readily oxidizable organic matter and heavy metals ( $\mathrm{Cd}, \mathrm{Co}, \mathrm{Cr}, \mathrm{Cu}, \mathrm{Ni}, \mathrm{Pb}, \mathrm{V}, \mathrm{Zn})$. Temperature within sediment ( $1 \mathrm{~cm}$ depth) and depth was determined in situ using a mercury thermometer $\left(0.1{ }^{\circ} \mathrm{C}\right.$ accuracy) and a diving barometer $(0.1 \mathrm{~m}$ accuracy) respectively.

\subsection{Sample processing}

Samples for meiofauna were sieved by 500 and $45 \mu \mathrm{m}$ mesh size; material retained on the smallest mesh size was collected. Sorting of meiofauna from sediment was done by flotation technique in high density solution (commercial sugar crystals dissolved in filtered water, $\left.1.17 \mathrm{~g} \mathrm{~cm}^{-3}\right)$; the efficiency of sorting using this method is around 95\% (Armenteros et al., 2008). Sorted meiofauna was stained with alcoholic eosin $1 \%$ and preserved in buffered formalin $4 \%$. Meiofauna was observed under stereomicroscope (maximum magnification $36 \times$ ); the animals were identified to high taxonomic level (e.g. nematodes, copepods) and counted. The first 100 nematodes (if present) were picked out, mounted in microscope slides (Vincx, 1996) and identified to putative species using a microscope (maximum magnification $1000 \times$ ). The pictorial keys of Platt and Warwick (1983, 1988), Warwick et al. (1998) and the NeMys Database (Deprez et al., 2007) were used for the identification of species.

The content of silt + clay was determined by "silt content-dry sediment" method after Bale and Kenny (2005). By this method the silt + clay fraction was separated on a $63 \mu \mathrm{m}$ sieve and the retained sediment was weighted for determination of the loss of sediment. The amount of readily oxidizable organic matter in the sediment was determined by the modified Walkley-Black wet titration method (Loring and Rantala, 1992) using oxidation with $\mathrm{K}_{2} \mathrm{Cr}_{2} \mathrm{O}_{7}$ and $\mathrm{H}_{2} \mathrm{SO}_{4}$. The concentration of heavy metals was determined, after acid total digestion (nitric and sulphuric acids during $48 \mathrm{~h}$ ), by flame atomic absorption using an Avanta 3000 (GBC) Atomic Absorption Spectrophotometer with air/acetylene flame and autosampler. All used reagents were pure for analysis.

\subsection{Biological traits of the nematode assemblages}

Each nematode species was classified into four different biological traits based on its morphological and functional features:

(1) Feeding types based on morphology of buccal cavity. Wieser (1953) classified the free-living nematodes into four feeding types: selective deposit feeder (1A), non-selective deposit feeder (1B), epigrowth feeder (2A) and omnivore/predator (2B). In addition, ratio of percentage of $1 \mathrm{~B}$ and $2 \mathrm{~A}$ types (i.e. $1 \mathrm{~B} /$ 2A) was calculated since it can be an indicator of contamination (Lambshead, 1986).

(2) Life strategy. Bongers (1990) and Bongers et al. (1991) proposed a scale (c-p score) to classifying the genera of nematodes upon their ability for colonising or persisting in a certain habitat. The scale range is defined from extreme colonisers ( $c-p$ score $=1$ ) to extreme persisters $(c-p$ score $=5$ ). Also, a maturity index (MI) can be calculated for each habitat/station based on c-p scores of inhabiting species using the formulae (Bongers et al., 1991):

$\mathrm{MI}=\sum_{i=1}^{s}(v x f)$

where $S=$ number of species, $v=$ the c-p value of $\operatorname{taxon} i$ and $f=$ the frequency of that taxon.

(3) Tail shape. Thistle et al. (1995) proposed a classification (may be linked to locomotion mode) of deep-sea nematodes on basis of tail shape into four types: rounded (1), clavate-conicocylindrical (2), conical (3), and long (4).

(4) Body shape. We used the operative classification by Schratzberger et al. (2007) who recognized three body shape categories: stout (length-width ratio $<18$ ), slender (length-width ratio $18-72$ ), and long/thin (length-width ratio $>72$ ).

\subsection{Data analysis}

Multi- and univariate techniques were used for data analysis using the software PRIMER 6.0.2 (Clarke and Gorley, 2006) and STATISTICA 6.0 from StatSoft. Statistical differences among stations and months were tested by two-way analysis of variance (ANOVA) for the quantitative information of the nematode assemblages: density, number of nematode species, maturity index and proportion of epigrowth feeding type. The latter was chosen as it is probably the feeding type with less overlapping with the other ones. For the analysis of vertical distribution a randomized block design was applied, defining stations as blocks and vertical strata as main factor. Data were checked for fulfilment of parametric assumptions using diagnostic graphics (mean vs variance, residuals vs mean); when needed, data were transformed and re-checked to ensure that transformation improved the distribution. If results of ANOVA with transformed data coincide with untransformed ones, the latter were presented in graphs for easier interpretation. The magnitude of effects for each factor was calculated after Underwood (1997) in order to compare the relative importance of each factor in determining significant differences. When the results of ANOVA were significant, a post-hoc multiple comparison of means (Student-Newman-Keuls, SNK) was carried out. If there were low number of replicates (i.e. analysis of vertical distribution) post-hoc comparisons were not performed to avoid the possible low statistical power of the tests. Relationships between measurements of assemblages and abiotic factors were tested by the Pearson's product-moment correlation with untransformed data.

Statistical differences in multivariate structure of assemblages among samples were tested by analysis of similarity (ANOSIM) using a similarity matrix based on fourth-root transformed density of nematode species. An ordination plot of samples using non-metric multidimensional scaling was performed on the same matrix. Principal component analysis was carried out for the ordination of samples and variables on basis of abiotic factors; the latter were normalized due to different units of measurement. Relationships between multivariate structure of community and subsets of abiotic factors were determined by BIOENV procedure, using Spearman's correlation between similarity matrices. 


\section{Results}

\subsection{Abiotic environment}

A table with all abiotic factors measured in the study is shown in Appendix 1 . The stability of temperature and salinity across stations in the same month suggest a good mixing of water within the Bay. Temperature showed a clear temporal change, with the interstitial water in February (dry season) colder than in May and September (wet season). Salinity was stable also across stations, with lowest salinity in February compared with May and September. The content of silt + clay and organic matter was high for all stations, the variation was relatively small ( $\mathrm{CV}=18$ and $23 \%$ respectively), and correlation between both variables was low $(r=0.29, p>0.05$, $n=18$ ). Presence of hydrogen sulphide was apparent in sediments of the deepest stations $(5,7 \mathrm{a}$, and 15$)$ as indicated by the strong characteristic smell of gas and by the dark colour of the sediment; the upper oxygenated layer of sediment was only a few millimetres thick based upon visual assessment of the darkness of sediment below.

The levels of cadmium and lead in sediments were below the limits of detection (2.1 and $27.8 \mathrm{mg} \mathrm{kg}^{-1} \mathrm{DW}$ respectively). The concentration of heavy metals in the sediments was different among stations, with relatively small temporal changes in the same station. Nevertheless, these spatial trends were not the same for all metals (Fig. 2): nickel, vanadium and zinc showed a similar trend, with highest values in station 10 (close to thermoelectric plant power), and lowest values in station 12a. Chromium showed a different trend, with highest values in stations 5 and $7 \mathrm{a}$; and cobalt and copper showed the highest values in station 15

\subsection{Density and number of species}

Seven meiofauna taxa were collected in the three sampling events: Nematoda, Copepoda, Polychaeta, Decapoda, Sipuncula, Ostracoda, and Kynorhyncha. The Nematoda counted for $98 \%$ of total density of meiofauna, therefore the main effort was devoted to

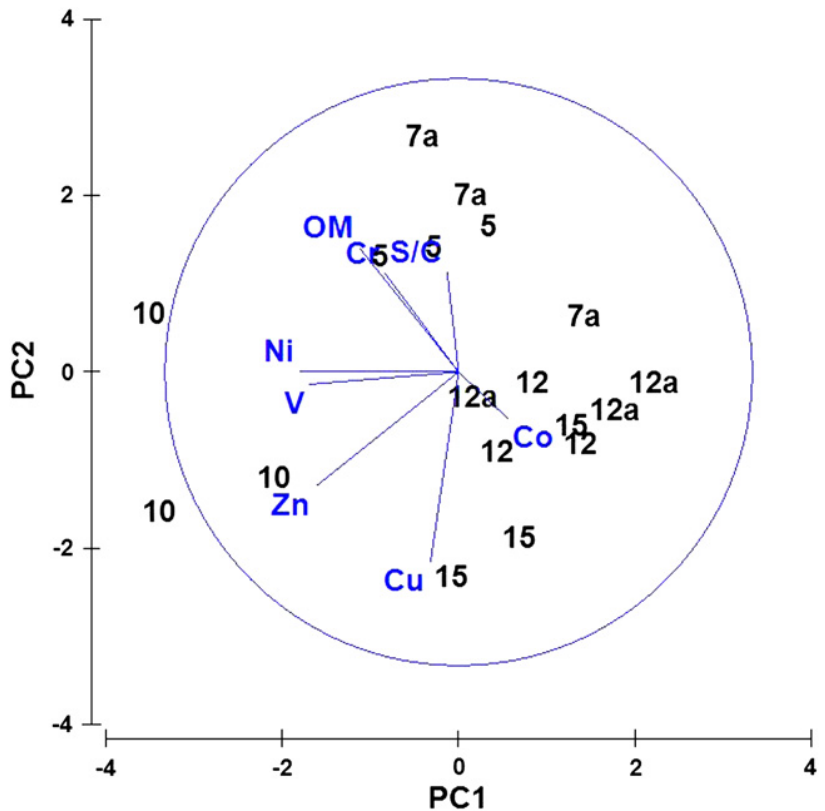

Fig. 2. Principal component analysis based on sedimentary abiotic factors measured in six stations and three months. The percentage of explained variance by the two first PCs: $57 \% . \quad \mathrm{OM}=$ organic matter, $\mathrm{S} / \mathrm{C}=$ silt + clay. The equation of axes: $\mathrm{PC} 1=-0.54 \mathrm{Ni}-0.51 \mathrm{~V}-0.48 \mathrm{Zn}-0.34 \mathrm{OM}-0.25 \mathrm{Cr}+0.17 \mathrm{Co}-0.10 \mathrm{Cu}-0.04 \mathrm{~S} / \mathrm{C}$. $\mathrm{PC2}=-0.65 \mathrm{Cu}+0.42 \mathrm{OM}-0.39 \mathrm{Zn}+0.34 \mathrm{~S} / \mathrm{C}+0.34 \mathrm{Cr}-0.16 \mathrm{Co}-0.04 \mathrm{~V}+0.003 \mathrm{Ni}$. their ecological patterns. Copepods ranked second in abundance, with low abundance in station 12 (mean \pm SD of three months: $22 \pm 21$ ind. $10 \mathrm{~cm}^{-2}$; range: $2-55$ ind. $10 \mathrm{~cm}^{-2}$ ) and practical absence in other stations.

The density of nematodes was significantly different among months, stations and in the interaction after two-way ANOVA (Table 1); ANOVA results on untransformed data of density showed the same trends. The magnitude of effect was the highest for factor station (spatial scale) and in second place for the interaction. The interpretation of latter suggests that density varied widely across stations and months and no clear trends exist (Fig. 3); given the high variance in values of density no any post-hoc comparison was done. The mean \pm SD values (range) of density of nematodes over all samples were $765 \pm 772$ (21-4596) individuals $10 \mathrm{~cm}^{-2}$.

The number of nematode species was significantly different among stations; however, the factors month and interaction station $\times$ month were not significant and they had a considerably lesser effect on number of species (Table 1). Consistently, station 12 had the highest number of species in the three months (Fig. 3) (SNK, $p<0.05$ ); the post-hoc multiple comparisons could not detect differences among the other five stations (SNK, $p>0.05$ ). The mean $\pm \mathrm{SD}$ (range) value of number of species over all samples was $12 \pm 5(4-26)$ species $10 \mathrm{~cm}^{-2}$.

\subsection{Taxonomic composition of nematode assemblages}

A list of all recorded nematode species and their mean density in each combination station-month is presented in Appendix 2. A total of 78 nematode species belonging to 18 families were identified. There was a strong dominance with sixty species contributing individually to less than $1 \%$ to total density (all samples combined). Ten species (belonging to five families) accounted for $80 \%$ of nematode total density: Terschellingia longicaudata (21\%), Sabatieria pulchra (14\%), Terschellingia communis (9\%), Macrodontium gaspari (8\%), Terschellingia gourbaultae (7\%), Cienfuegia cachoi (5\%), Sabatieria breviseta (5\%), Pseudoterschellingia ibarrae (4\%), Spirinia parasitifera (3\%), and Metachromadora pulvinata (3\%).

The most spatially widespread nematode species was Terschellingia longicaudata, followed by Terschellingia gourbaultae, Sabatieria breviseta, and Sabatieria pulchra (Appendix 2). Several

Table 1

Results of analyses of variance on univariate measurements of nematode assemblages. Double line separates two designs: upper, two-way ANOVA testing differences among stations and months (df error $=53$ ); below, randomized block ANOVA testing differences in vertical distribution ( $\mathrm{df}$ error $=31$ ). $\mathrm{MS}=$ mean square, $\mathrm{df}=$ degrees of freedom, $p=$ probability. Significant results in bold type.

\begin{tabular}{llrrcc}
\hline Metric & Factor & MS & df & $p$-value & Effect size \\
\hline Density (log-transformed) & Station & $\mathbf{1 2 . 1}$ & $\mathbf{5}$ & $<\mathbf{0 . 0 0 1}$ & $\mathbf{0 . 8}$ \\
& Month & $\mathbf{2 . 4}$ & $\mathbf{2}$ & $\mathbf{0 . 0 1 3}$ & $\mathbf{0 . 0 5}$ \\
& Station $\times$ month & $\mathbf{2 . 7}$ & $\mathbf{1 0}$ & $<\mathbf{0 . 0 0 1}$ & $\mathbf{0 . 3}$ \\
Number of species & Station & $\mathbf{2 5 2 . 1}$ & $\mathbf{5}$ & $<\mathbf{0 . 0 0 1}$ & $\mathbf{1 6 . 9}$ \\
& Month & 22.0 & 2 & 0.089 & 0.3 \\
& Station $\times$ month & 6.5 & 10 & 0.68 & 0.3 \\
\% Epigrowth feeders & Station & $\mathbf{3 4 9 0 . 6}$ & $\mathbf{5}$ & $<\mathbf{0 . 0 0 1}$ & $\mathbf{2 3 5 . 8}$ \\
(rank transformed) & Month & $\mathbf{6 3 8 . 4}$ & $\mathbf{2}$ & $\mathbf{0 . 0 0 2}$ & $\mathbf{1 5 . 2}$ \\
& Station $\times$ month & $\mathbf{5 8 9 . 7}$ & $\mathbf{1 0}$ & $<\mathbf{0 . 0 0 1}$ & $\mathbf{6 8 . 8}$ \\
Maturity index & Station & $\mathbf{0 . 4}$ & $\mathbf{5}<\mathbf{0 . 0 0 1}$ & $\mathbf{0 . 0 3}$ \\
& Month & 0.004 & 2 & 0.71 & $<0.001$ \\
& Station $\times$ month & $\mathbf{0 . 0 5}$ & $\mathbf{1 0}$ & $<\mathbf{0 . 0 0 1}$ & $\mathbf{0 . 0 0 6}$ \\
Density (log-transformed) & Stratum & $\mathbf{5 . 8}$ & $\mathbf{3}$ & $\mathbf{0 . 0 0 2}$ & $\mathbf{0 . 5}$ \\
& Station & $\mathbf{4 . 1}$ & $\mathbf{4}$ & $\mathbf{0 . 0 0 7}$ & $\mathbf{0 . 4}$ \\
Number of species & Stratum & $\mathbf{4 4 . 0}$ & $\mathbf{3}$ & $\mathbf{0 . 0 0 4}$ & $\mathbf{3 . 6}$ \\
& Station & $\mathbf{4 1 . 2}$ & $\mathbf{4}$ & $\mathbf{0 . 0 0 3}$ & $\mathbf{4 . 4}$ \\
\% Epigrowth feeders & Stratum & 288.6 & 3 & 0.10 & 16.0 \\
(rank transformed) & Station & 247.4 & 4 & 0.13 & 15.9 \\
Maturity index & Stratum & 0.07 & 3 & 0.44 & 0.001 \\
& Station & $\mathbf{0 . 2 5}$ & $\mathbf{4}$ & $\mathbf{0 . 0 2 2}$ & $\mathbf{0 . 0 2}$ \\
\hline
\end{tabular}



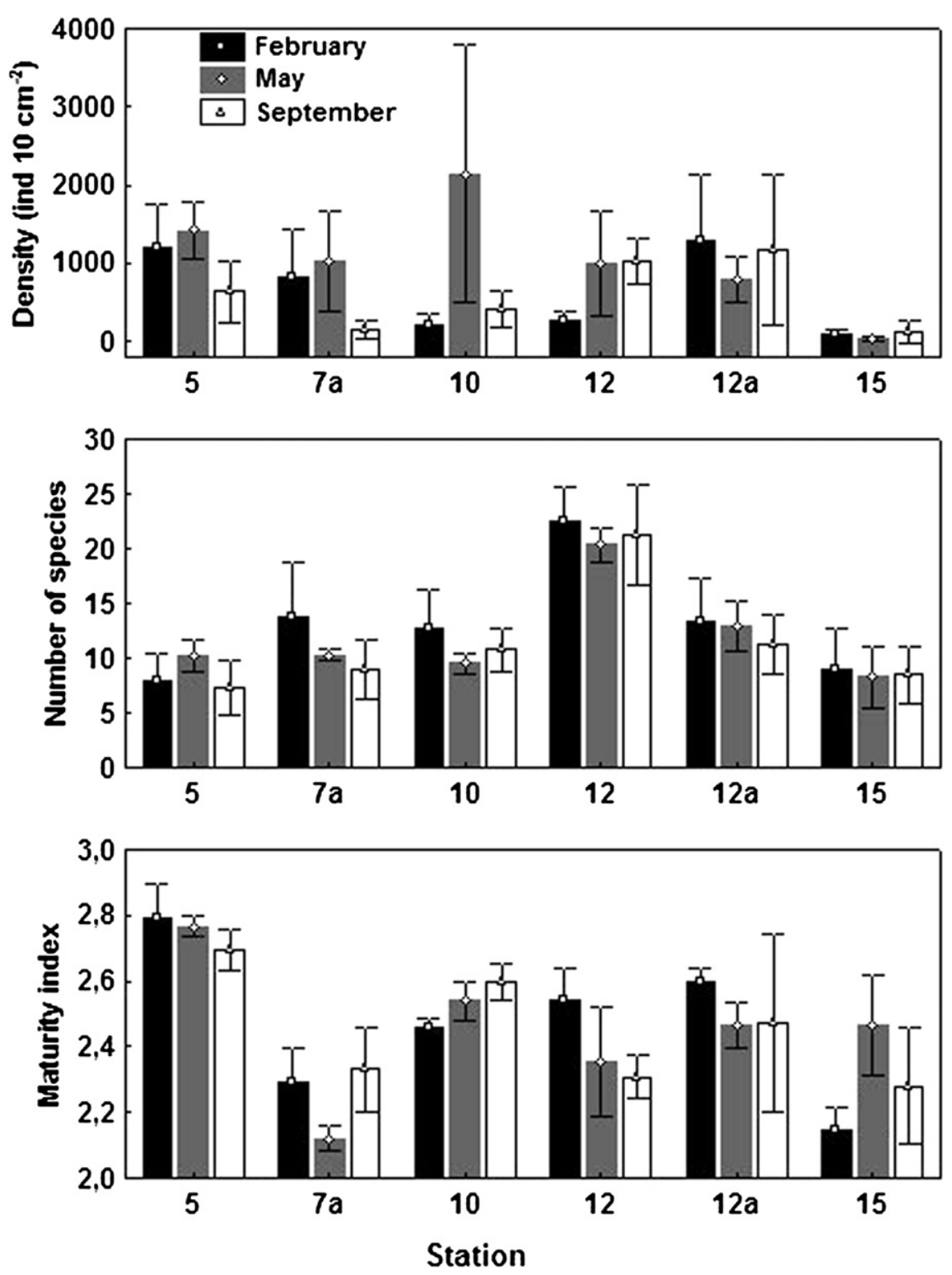

Fig. 3. Mean \pm standard deviation $(n=4)$ of univariate measurements of nematode assemblages in six stations and three months.

species appears to be characteristic of particular stations: Macrodontium gaspari (stations 10 and 12a), Cienfuegia cachoi (stations 5 and 7a), Metacyatholaimus chabaudi (station 12), and Dorylaimopsis punctata, Hopperia muscatensis and Vasostoma sp. (station 15). In addition, other species showed a strongly patched spatial-temporal distribution, i.e. appearing only in one station and one month in high density; for instance: Pseudoterschellingia ibarrae (7a on May) and Spirinia parasitifera (12a on February).

A two-way analysis of similarity (ANOSIM) on fourth root transformed data of density showed clear global differences in structure of assemblages among stations $(R=0.84 ; p<0.001 ; 999$ permutations) and among months $(R=0.71 ; p<0.001 ; 999$ perm. $)$. The pair-wise comparisons showed differences $(p<0.001)$ between each pair of stations, and between each pair of months as well. The ordination of samples by multidimensional scaling (MDS) technique showed clear differences among stations, but not so clear among months (Fig. 4). Most of the samples (i.e. cores) belonging to a same station and/or month were clustered together; particularly the stations 12 and 15 have a very distinctive assemblage structure; the latter station is characterized also by higher variability.

\subsection{Biological traits}

We analyzed each trait individually and the combination of them as well. There was negative and significant correlation among percentage of the three dominant feeding types: selective deposit feeders (1A), non-selective deposit feeders (1B) and epigrowth feeders (2A). Therefore, we tested differences among stations and months just for percentage of type 2A. The results of two-way ANOVA on rank-transformed data showed significant differences in percentage of feeding type $2 \mathrm{~A}$ for the factors station, month and the interaction; again the magnitude of effect was bigger for factor station, and in second place for the interaction (Table 1). An ANOVA performed on untransformed data showed also significant differences for the factors station, month and interaction station $\times$ month.

The feeding type composition was characterized by dominance of selective deposit feeders $(37 \pm 3 \%)$ and epigrowth feeders (37 $\pm 1 \%$ ) over all samples; non-selective deposit feeders and predator/omnivore types account for 15 and $11 \%$ respectively. The stations 12 and 15 were characterized by a relatively stable feeding 


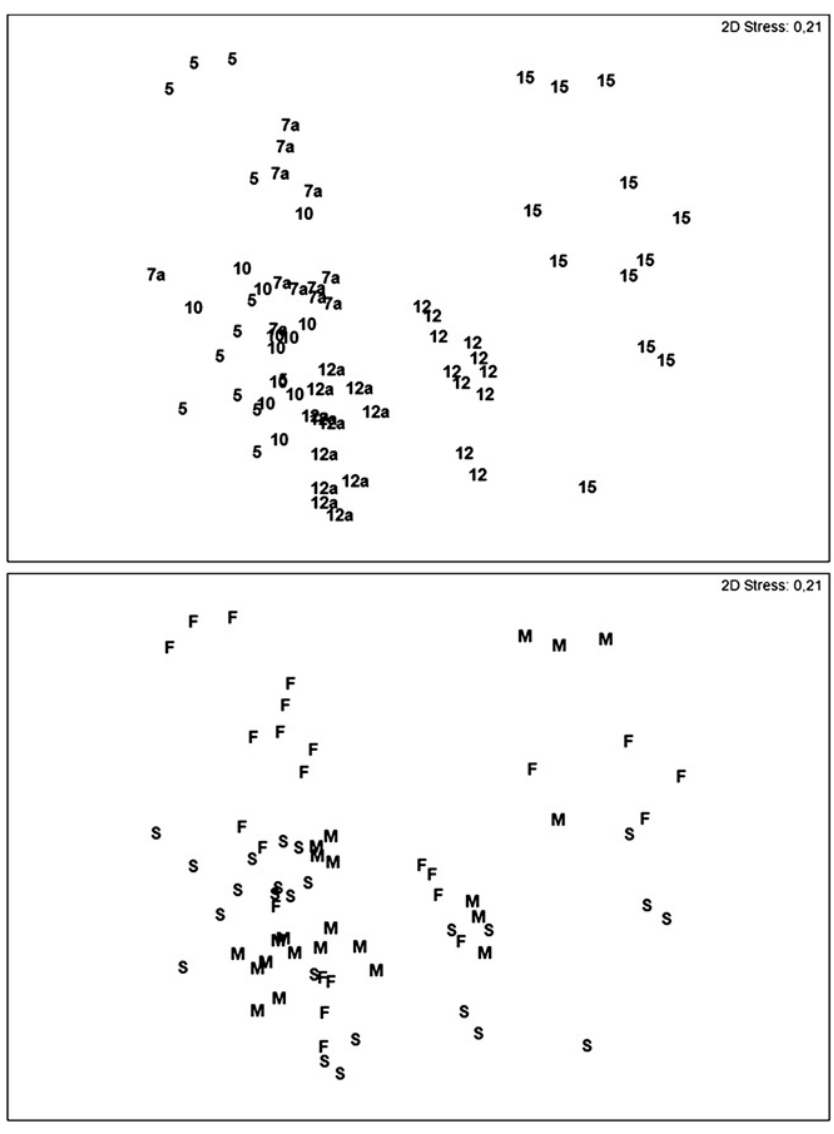

Fig. 4. Multidimensional scaling plots of nematode assemblages based on fourth-root transformed data of density from six stations and three months. The plots are coded by stations and by months. The labels of the samples: $\mathrm{F}=$ February, $\mathrm{M}=\mathrm{May}$, and $\mathrm{S}=$ September; the number indicates the station.

type composition across the three sampling events, with a rather balanced representation of the four feeding types (Fig. 5). Station 5 showed dominance of selective deposit feeding nematodes across the three sampling events, whereas station 7a was dominated by non-selective deposit feeders; in the station 10 both named types (1A and $1 \mathrm{~B}$ ) were equally abundant (Fig. 5). Station 12a showed a strong temporal change in trophic structure, with notable decrease of epigrowth feeding nematodes in May. The $1 \mathrm{~B} / 2 \mathrm{~A}$ ratio for each combination of station and month did not show clear spatial or temporal trends, to exception of the highest values in station 7a in all sampled months (Appendix 2).

The maturity index was calculated for each combination of station-month; and it showed significant differences among stations and in the interaction with higher magnitude of effect for factor station (Table 1). Station 5 showed consistently a higher value of the index (month-averaged $\mathrm{MI}=2.75$ ) in comparison with other stations (range 2.25-2.53); the stations 7a and 15 showed the lowest MI values and also the higher monthly variance (Fig. 3).

Most of the nematodes (57\%) had a clavate-conicocylindrical tail shape (type 2), the tail shape long/filiforme ranked in second place (35\%). There was no clear trend in the percentage of tail shape across stations or months. The body shape of nematodes was mainly slender ( $97 \%$ of total of nematodes) and in less proportion long/thin; there was absence of nematodes of stout bodies.

The combination of the four biological traits produced a total of 28 morphotypes; the number of morphotypes was highly correlated to number of species $(r=0.94 ; p<0.05 ; n=71)$. Just three morphotypes contribute to $65 \%$ of total abundance: (1) nonselective deposit feeder/c-p 2/tail conico-cylindrical/body slender: corresponded to species Sabatieria breviseta, Sabatieria praedatrix, Sabatieria pulchra, Daptonema oxycerca and Pseudoterschellingia ibarrae; (2) selective deposit feeder/c-p 3/tail filiforme/body slender: corresponded to Terschellingia longicaudata; (3) selective deposit feeder/c-p 3/tail conico-cylindrical/body slender: corresponded to Terschellingia communis and Terschellingia gourbaultae.

\subsection{Vertical distribution}

The samples analyzed for description of vertical distribution included 53 species of nematodes (70\% of total number of species recorded for the three sampling periods). Randomized block analyses of variance was applied to the four univariate measurements of assemblages. There were significant differences in log-transformed density of nematodes among vertical strata and among blocks (Table 1); the non-transformed data of density showed significant differences only among strata. The general trend was a higher density in surface layers of sediment $(0-1$ and $1-2 \mathrm{~cm})$, and less than 100 nematodes $10 \mathrm{~cm}^{-2}$ in deeper strata (Fig. 6). However, a vertical gradient in density was not so clear in stations 7 a and 15 .

The number of nematode species showed significant differences among vertical strata and among stations (Table 1). Non-transformed data showed the same trend. There was a clear reduction in number of species in deeper strata, with less than seven species in 4-6 cm stratum (Fig. 7). Analyses of variance failed to detect of significant differences among strata within sediment for variables: rank-transformed percentage of epigrowth feeder and maturity index (Table 1). No any clear vertical trends were evident in both of these variables (graphs not showed).

A two-way cross ANOSIM permutation test showed statistical differences in multivariate composition of assemblages among stations $(R=0.70 ; p<0.001 ; 999$ perm.), but there are no statistical differences among vertical strata within sediment $(R=0.12$; $p=0.16$; 999 perm.). Pair-wise comparisons had few possible permutations due to low level of replication; therefore they were not performed. The ordination by MDS of samples was characterized by differences among stations, but there is no particular grouping of samples by vertical strata (plot not presented). With regard to species, the following three species appeared in all strata: Sabatieria breviseta, Spirinia parasitifera, and Terschellingia longicaudata. We did not detect species restricted to deep strata; instead, most of them occurred only in the surface strata. There was no clear spatial pattern of biological traits (i.e. feeding types, tail shape, and body shape) in the vertical distribution within sediments.

\subsection{Relationships nematodes-abiotic environment}

Univariate correlations were performed between four measurements of nematode assemblage (i.e. density, number of species, \% epigrowth feeders, and maturity index) and the set of twelve abiotic factors. The only measurement that showed a significant correlation with any environmental factor was the density of nematodes; it was correlated with depth $(r=-0.49$; $p<0.05 ; n=18)$ and with silt/clay percentage $(r=-0.58 ; p<0.05$; $n=18)$.

BIOENV procedure was applied on similarity matrices derived from density data for nematode species, individual biological traits (e.g. feeding type, life strategy, tail shape, body shape), and a combination of the four traits (Table 2 ). In general, heavy metals $(\mathrm{Co}, \mathrm{Cu})$ and depth show the best matching with multivariate biological pattern. Interestingly, matrix of similarity based on life strategy suggests an additional putatively important variable: organic content, while matrix based on combined biological traits 

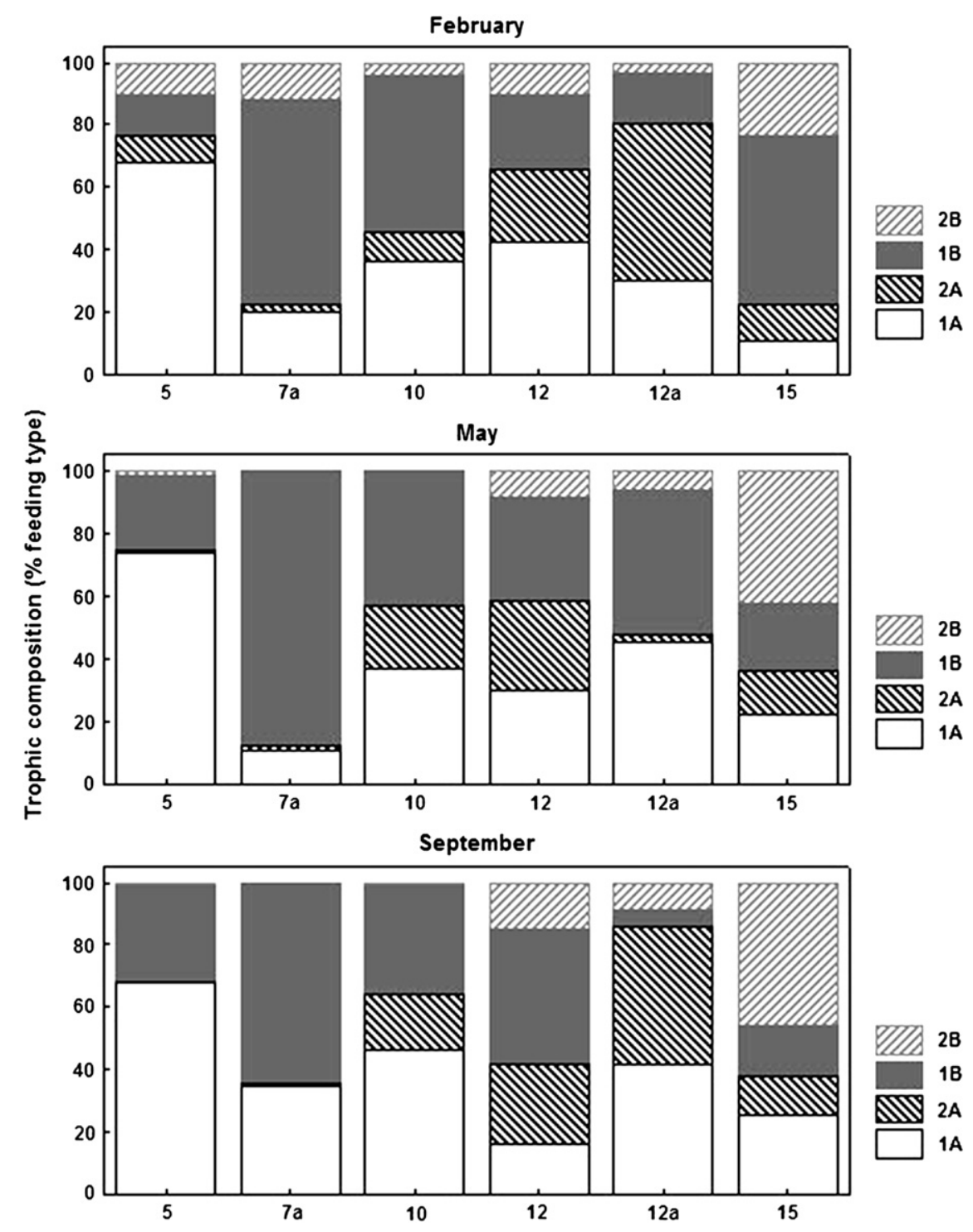

Fig. 5. Trophic composition of nematode assemblages on basis of average percentages in six stations for three months. The feeding types defined after Wieser (1953): $1 \mathrm{~A}=$ selective deposit feeders, $2 \mathrm{~A}=$ non-selective deposit feeders, $2 \mathrm{~A}$ = epigrowth feeders, $2 \mathrm{~B}=$ predators/omnivores.

matrix suggests the silt/clay content as other variable with explanatory power.

\section{Discussion}

The integration of our results provided a quantitative description of the biodiversity patterns of free-living marine nematodes in Cienfuegos Bay in temporal (month) and spatial (horizontal and vertical) scales, and also a relatively good characterization of the abiotic environment including natural and pollution related variables. In order to address the most relevant topics arising from our results we divided this section following the three main research questions presented in Introduction.

\subsection{Does the biological trait approach provide new interpretable information in comparison to a "classical" taxonomic approach?}

In present study, the biological trait approach shows a possible influence of two key abiotic factors on nematode assemblages: organic content and silt/clay fraction in sediment. This information could not be clearly deducted from the analysis of the species matrix and it is relevant in the context of factors affecting the structure of assemblages (for discussion see next topic). Despite the different spatial scales used in present study (few kilometres) and in the study by Schratzberger et al. (2007) two features are common for both studies: (1) biological trait approach is not more powerful than taxonomic approach in detecting spatial patterns; but (2) biological trait approach offers more reliable correlative links with environmental factors than taxonomic one.

The significant correlation between number of morphotypes and number of species supports the hypothesis that the increase of species richness can lead to potential increases of functional diversity (Schratzberger et al., 2007). However, the high spatial turnover of rare species occurring in Cienfuegos Bay probably does not mean a change in the functioning of the ecosystem since most of the species are detritivores with a relatively low degree of specialisation and carrying out similar ecosystem processes (Hooper et al., 2005). The strong dominance of only two morphotypes (deposit feeder/c-p 2 or 3/tail conical cylindrical or filiforme/ body slender) across months and stations is consistent with the 

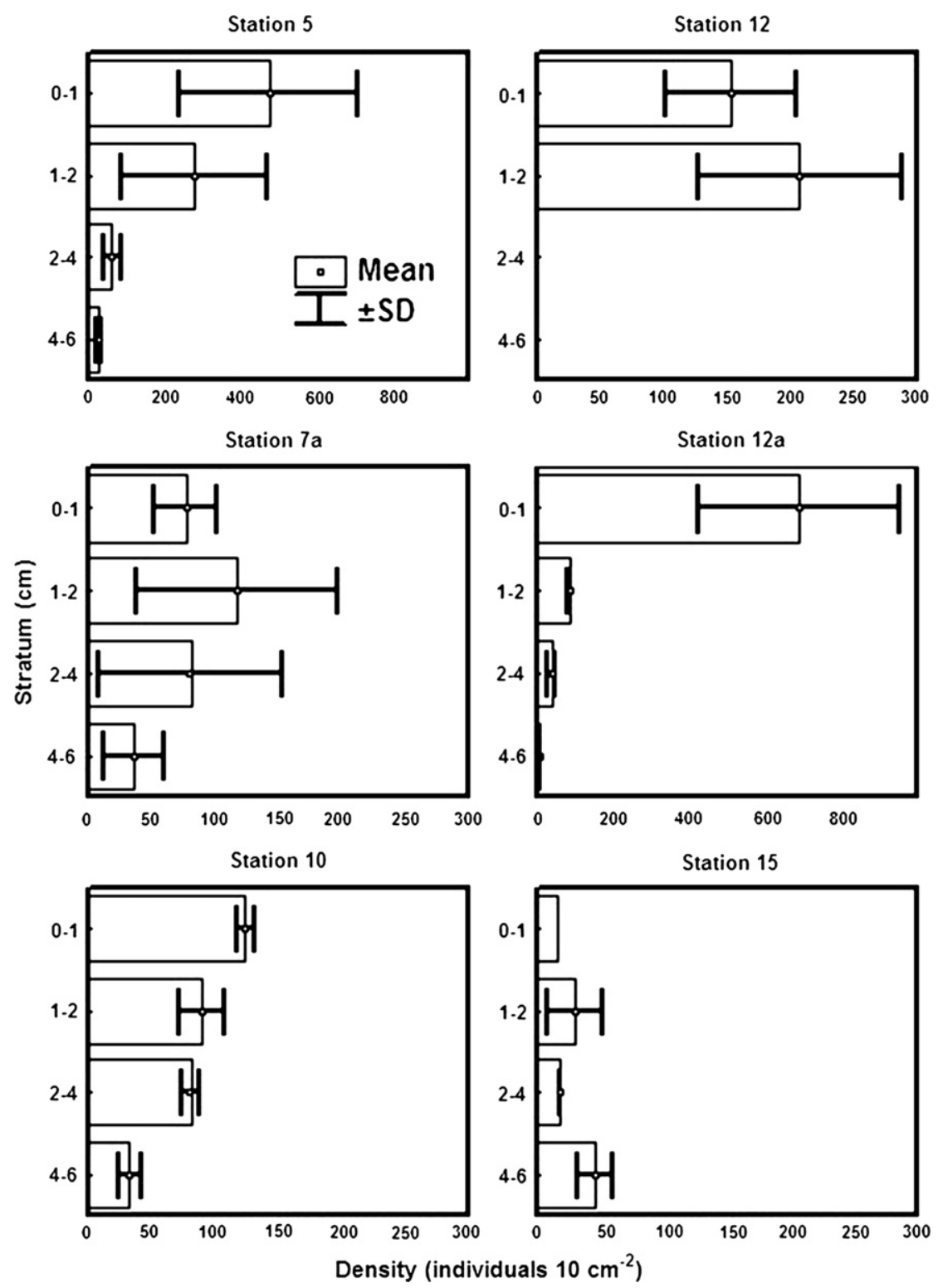

Fig. 6. Mean \pm standard deviation $(n=2)$ of density of nematode assemblages in four vertical strata within sediment and in six stations in February 2006 . Note that scales on $x$-axis are not the same. In station 12 , strata 2-4 and 4-6 were not sampled.

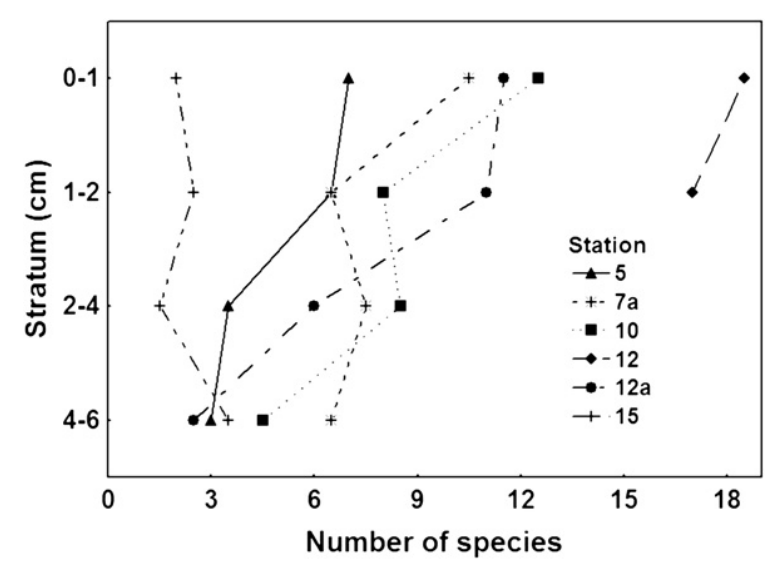

Fig. 7. Mean values of number of species of nematodes in four vertical strata within sediment and in six stations in February 2006. In station 12, strata 2-4 and 4-6 were not sampled. relatively high homogeneity of the studied muddy bottoms and with the small spatial scale of this study; it means that we are dealing with a habitat species pool instead of a regional pool (Emerson and Gillespie, 2008).

Our findings strongly encourage the analysis of biological traits, in addition to analysis by species, when diversity patterns and

Table 2

Results of BIOENV analysis for matrices of similarity derived from data of density of species and biological traits. The combination of abiotic factors with highest value of Spearman rank correlation $(\rho)$ and significance values $(p)$ are shown.

\begin{tabular}{llll}
\hline Matrix & $\rho$ & $p$ & Abiotic factors \\
\hline Species & 0.60 & 0.01 & Depth, Co, Cr, Cu \\
Feeding type & 0.50 & 0.03 & Depth, Co, Cu \\
Life strategy & 0.49 & 0.01 & Organic content, Co, Cu \\
Tail shape & 0.43 & 0.02 & Depth, Co, Cu \\
Body shape & 0.58 & 0.01 & V, Co \\
Combined biological traits & 0.60 & 0.01 & Depth, silt + clay, Co, Cr, Cu \\
\hline
\end{tabular}


related ecological processes are the aims of the investigation. Biological trait approach can overcome two of the weak points/sides of taxonomic approach, namely: (1) ratio response/noise in species data sets can be substantially low due to latter are typically characterized by strong fluctuations in values of abundance, high numbers of zeros and marked skewness in distribution; and (2) problems of misidentification of some species complex with high morphological similarity (e.g. Terschellingia and Sabatieria) are less critical in the context of biological traits. Additionally, the classification of nematode species into functional traits can reveal more straightforward links between diversity and ecosystem functioning; or not. For macrofauna, some studies (e.g. Bolam et al., 2002) emphasizes importance of functional traits over species richness in the effects on ecosystem functioning, while other studies (e.g. Ieno et al., 2006; Norling et al., 2007) suggest that identity of species (i.e. idiosyncratic response) plays a key role in determining these effects. To our knowledge no data exist for marine nematodes regarding the relationship diversity (taxonomic, biological trait, etc.) - ecosystem functioning, being a promising research avenue.

\subsection{Which natural and/or anthropogenic processes determine the biodiversity patterns of free-living nematodes within the Bay?}

The integration of information about environmental quality of Cienfuegos Bay strongly suggests that the ecosystem is subjected to organic (e.g. petroleum) and inorganic pollution (e.g. heavy metals). Spatial changes in the multivariate structure of assemblages and abiotic data reinforce the existence of two well characterized basins within Cienfuegos Bay, a northern basin, more polluted than the southern basin. Historical records of contamination within sediments using nuclear techniques suggest that relatively high levels of $\mathrm{Co}, \mathrm{Cr}$, and $\mathrm{Cu}$ in southern basin are of natural origin (C. Alonso, Centro de Estudios Ambientales de Cienfuegos, Cuba, pers. com.). However contamination by other heavy metals persists and a comparison with reference values (Long et al., 1995) indicates concentration higher than threshold values causing biological effects in all stations.

Although heavy metals in sediments have harmful effects on nematode assemblages (Lampadariou et al., 1997; Gyedu-Ababio and Baird, 2006; Hedfi et al., 2007) toxicity to nematode populations inhabitant Cienfuegos Bay can be reduced by the high organic content in sediments (Rzeznik-Orignac et al., 2003; GyeduAbabio and Baird, 2006) and relatively high salinity (Dauvin, 2008). In addition, nematode species from Cienfuegos Bay probably have developed tolerance to chronically metal-enriched habitats, a process discussed by Millward and Grant (1995) for an estuary.

We suggest that a combination of organic enrichment-hypoxiahydrodynamic regime drive (in interaction with pollution) the biodiversity patterns of nematode assemblages. Low hydrodynamic regime could explain the existence of a thick flocculent layer (M. Armenteros, pers. observation), high content of silt + clay in sediments, and high sedimentation rate in the bed of the deepest stations (Alonso-Hernandez et al., 2006). These features are mostly associated with a stable near-bed stratification of bottom water (Friedrichs et al., 2000) which can reduce the passive dispersal of small-size organisms (Silvester and Sleigh, 1985) resulting in the highly patchy distribution of nematode assemblages observed in the bay. The low hydrodynamic regime probably enhances the negative effects of organic enrichment and hypoxia on the benthos (Snelgrove and Butman, 1994; Gray et al., 2002), and this synergistic relationship can be particularly important in semi-enclosed bays (Kröger et al., 2006). Dominant species in Cienfuegos Bay (belonging to genera Terschellingia, Sabatieria and Daptonema) are typical of poorly oxygenated and organically enriched bottoms around the world, and they appear tolerant to a variety of xenobiotic compounds (Soetaert et al., 1994; Schratzberger et al., 2006; Steyaert et al., 2007). Also, the dominance of the species T. longicaudata supports the idea of a relatively undisturbed physically environment (but chemical pollution still existing) because it is sensitive to physical disturbance as was demonstrated in experimental conditions (Schratzberger and Warwick, 1999).

The hydrodynamic regime also can influence the vertical distribution of nematodes in muddy bottoms (Soetaert et al., 1994; Steyaert et al., 2003); however, centimetre-scale distribution patterns of nematodes in Cienfuegos Bay (i.e. vertical distribution) would be determined in larger extension by biotic interactions (Zajac et al., 1998). For instance, in polluted and very fine sediments, pollution-tolerant deposit feeding species belonging to genera Sabatieria and Terschellingia are dominant. The dominance of one or another species may be the result of interspecific competition for food or space: In Cienfuegos Bay the larger body size of Terschellingia longicaudata compared to Sabatieria pulchra might offer an additional advantage (i.e. more pushing force) for inhabiting silty sediments where movements within sediments depend of burrowing abilities. Data from another heavily polluted tropical semi-closed bay (Havana Bay, unpublished data) showed a dominance of S. pulchra species over T. longicaudata linked may be due to coarser sediment in comparison with Cienfuegos Bay. Further research on interactions between these two sympatric and tolerant species should be addressed.

\subsection{How different are the biodiversity patterns in a tropical semi- enclosed bay in comparison with those in similar ecosystems in temperate regions?}

To our knowledge, the present study is the only one published describing biodiversity patterns of nematode assemblages in a tropical semi-closed bay. Our results show similar outputs with comparable habitats in temperate regions (Table 3); unfortunately, there are no data on unpolluted harbours/bays serving as reference. The comparison, suggests three general ideas that are discussed below: (1) anthropogenic disturbance has a strong influence on the patterns of meiofaunal distribution within these systems; (2) temporal trends are lacking or are overrided by spatial differences; and (3) there is a notable dominance of a few cosmopolitan genera/ species of nematodes tolerant to hypoxic and polluted conditions.

The pollution derived from harbourage activities, industrial development, and human settlements is one of the main factors determining distribution patterns in semi-enclosed bays included in Table 3; in addition, the negative effects are reinforced by reduced exchange of water with adjacent open water. Effects of pollution on benthos are closely dependent on location of sources of pollutants (e.g. cities, factories) and temporal changes in human activities causing pollution are usually of less importance. This can explain the stronger changes in response of meiofauna (and nematodes) to human disturbance in the spatial scale (e.g. among stations) than in the temporal one (e.g. months).

Data sets obtained from small scale studies (dealing with estimates of alpha-diversity) are not suitable for latitudinal comparisons of biodiversity patterns (dealing with gamma-diversity) (Gray and Elliott, 2009). However, we noted the high similarity of nematode assemblage composition between tropical and temperate bays regarding identity and number of genus/species (Table 3); this supports the cosmopolitan nature in the structure assemblage of free-living marine nematodes. Recent research (e.g. Bhadury et al., 2008; Derycke et al., 2008) using molecular DNAbased techniques indicate the existence of cryptic species complexes for some species-rich and cosmopolitan genera of nematodes; as result, may be cosmopolitism as revealed by the 
Table 3

Comparison of main biodiversity features of nematode assemblages in semi-closed bays/harbors. $\mathrm{MI}=$ maturity index.

\begin{tabular}{|c|c|c|c|c|}
\hline Bay/harbor & $\begin{array}{l}\text { Density (ind } 10 \mathrm{~cm}^{-2} \text { ), } \\
\text { diversity }\end{array}$ & $\begin{array}{l}\text { Dominant } \\
\text { genus/species }\end{array}$ & Ecological remarks & Reference \\
\hline $\begin{array}{l}\text { Iraklion, Crete (without } \\
\text { external station O) }\end{array}$ & Range $^{\mathrm{a}}$ : 0-2530 ind, 115 spp. & $\begin{array}{l}\text { Sabatieria, Metalinhomoeus, } \\
\text { Daptonema, Terschellingia, } \\
\text { Paracomesoma }\end{array}$ & $\begin{array}{l}\text { Clear spatial heterogeneity in } 100 \text { m-scale, } \\
\text { pollution and physical disturbance } \\
\text { shaping the distribution of assemblages }\end{array}$ & Lampadariou et al. (1997) \\
\hline Wrangel Bay, Sea of Japan & Mean: $538 \pm 87$ ind, 48 spp. & $\begin{array}{l}\text { Dorylaimopsis piculiaris, } \\
\text { Viscosia stenostoma, } \\
\text { Sabatieria pulchra, S. palmaris }\end{array}$ & $\begin{array}{l}\text { Spatial distribution depended of grain } \\
\text { size and heavy metal content in sediments }\end{array}$ & Pavlyuk et al. (2003) \\
\hline Genoa-Voltri, Italy & Mean: $225 \pm 25$ ind, 23 genera & $\begin{array}{l}\text { Paracomesoma, } \\
\text { Terschellingia, } \\
\text { Daptonema, } \\
\text { Desmodora, Sabatieria }\end{array}$ & $\begin{array}{l}\text { High dominance, lacking of temporal } \\
\text { distribution patterns, clear spatial } \\
\text { heterogeneity in } 100 \mathrm{~m} \text {-scale, pollution } \\
\text { rather than food supply are the main } \\
\text { ecological driven, MI was not sensitive }\end{array}$ & Moreno et al. (2008) \\
\hline $\begin{array}{l}\text { Victoria, Hong Kong } \\
\text { (stations B2 and B3) }\end{array}$ & Range $^{\mathrm{a}}$ : $13-272$ ind, 127 spp. & $\begin{array}{l}\text { Sabatieria praedatrix, } \\
\text { Terschellingia communis, } \\
\text { T. longicaudata, } \\
\text { Parodontophora sp. }\end{array}$ & $\begin{array}{l}\text { Coarse silt + very fine sand, } \\
\text { polluted habitat, no temporal } \\
\text { variation in nematode composition }\end{array}$ & Liu et al. (2008) \\
\hline $\begin{array}{l}\text { Cienfuegos Bay, } \\
\text { Caribbean Sea }\end{array}$ & Range: $21-4596$ ind, 78 spp. & $\begin{array}{l}\text { Terschellingia longicaudata, } \\
\text { Sabatieria pulchra, T. communis }\end{array}$ & $\begin{array}{l}\text { High dominance, lacking of temporal } \\
\text { patterns, clear spatial heterogeneity in } \\
100 \text { m-scale, pollution and depth linked } \\
\text { to structure of assemblages. MI } \\
\text { interpretation confused by } \\
\text { interaction of anthropogenic } \\
\text { and natural factors }\end{array}$ & Present study \\
\hline
\end{tabular}

${ }^{a}$ Values assessed from graphs.

molecular taxonomy is not so widely extended in marine nematode's realm.

\section{Conclusions}

(1) The biological trait approach added relevant information to taxonomic approach regarding relationships between diversity patterns of nematodes and the abiotic environment. Functional diversity of assemblages did not change appreciably in space and time, despite high turnover of species. This is probably due to relatively low heterogeneity of the studied soft bottoms but also because a local (habitat) pool of species was analyzed instead of regional one.

(2) Chemical pollution and hydrodynamic regime possibly drove the biodiversity pattern of nematode assemblages in Cienfuegos Bay. The low hydrodynamic regime could determine a poor dispersion of nematodes resulting in high spatial variance in assemblage structure and also the associated hypoxic conditions and pollutants in sediments could explain the dominance of tolerant nematode species.

(3) The spatial-temporal patterns of biodiversity of nematode assemblages in the studied semi-enclosed bays, both tropical and temperate, are characterized by similar features: strong influence of anthropogenic disturbance, temporal trends being weak or overridden by spatial ones, and dominance of a few genera/species tolerant to pollution and hypoxic conditions.

\section{Acknowledgements}

Financial support was provided by International Foundation for Science (Research Grant IFS A/4004-1 to M. Armenteros), and Ghent University (doctoral scholarship BOF 01W01607 to M. Armenteros; project BOF 01GZ0705 "Biogeography and Biodiversity of the Sea" to M. Vincx). We thank staff of Centro de Estudios Ambientales de Cienfuegos (CEAC), particularly Yusmila Helguera, Miguel Gómez and Misael Díaz-Asencio for the skilful help with the samplings and processing of samples. The Belgian Focal Point to the Global Taxonomy Initiative (project 2406JVG2) powered the taxonomic expertise in nematodes of Cuban authors. We acknowledge the support of the Laboratorio de Análisis Ambiental del CEAC for determinations of abiotic variables. D.S. McLusky and three anonymous referees contribute decisively with comments/criticisms to improve the manuscript.

\section{Appendix. Supplementary data}

Supplementary data associated with this article can be found in the online version, at doi:10.1016/j.ecss.2009.08.002.

\section{References}

Alonso-Hernandez, C.M., Díaz-Asencio, M., Muñoz-Caravaca, A., Delfanti, R Papucci, C., Ferretti, O., Crovato, C., 2006. Recent changes in sedimentation regime in Cienfuegos Bay, Cuba, as inferred from $210 \mathrm{~Pb}$ and $137 \mathrm{Cs}$ vertical profiles. Continental Shelf Research 26, 153-167.

Armenteros, M., Pérez-García, J.A., Pérez-Angulo, A., Williams, J.P., 2008. Efficiency of extraction of meiofauna from sandy and muddy marine sediments. Revista de Investigaciones Marinas 29, 113-118.

Bale, A.J., Kenny, A.J., 2005. Sediment Analysis and Seabed Characterization. In: Eleftheriou, A., McIntyre, A. (Eds.), Methods for the Study of Marine Benthos. Blackwell, Oxford, 409 pp. (Chapter 2).

Bhadury, P., Austen, M.C., Bilton, D.T., Lambshead, P.J.D., Rogers, A.D., Smerdon, G.R. 2008. Evaluation of combined morphological and molecular techniques for marine nematode (Terschellingia spp.) identification. Marine Biology 154, 509-518.

Bolam, S.G., Fernandes, T.F., Huxham, M., 2002. Diversity, biomass, and ecosystem processes in the marine benthos. Ecological Monographs 72, 599-615.

Bongers, T., 1990. The maturity index: an ecological measure of environmental disturbance based on nematode species composition. Oecologia 83, 14-19.

Bongers, T., Alkemade, R., Yeates, G.W., 1991. Interpretation of disturbance-induced maturity decrease in marine nematode assemblages by means of the Maturity Index. Marine Ecology Progress Series 76, 135-142.

Boucher, G., Gourbault, N.E., 1990. Sublitoral meiofauna and diversity of nematode assemblages off Guadeloupe Islands (French West Indies). Bulletin of Marine Science 47, 448-463.

Boucher, G., Lambshead, P.J.D., 1994. Ecological biodiversity of marine nematodes in samples from temperate, tropical, and deep-sea regions. Conservation Biology 9, 1594-1604.

Clarke, K.R., Gorley, R.N., 2006. Primer v6: User Manual/Tutorial. Primer-E, Ltd. Plymouth, $190 \mathrm{pp}$.

Dauvin, J.C., 2008. Effects of heavy metal contamination on the macrobenthic fauna in estuaries: the case of the Seine estuary. Marine Pollution Bulletin 57, 160-169.

Deprez, T., et al., 2007. NeMys. WWW page, http://www.nemys.ugent.be.

Derycke, S., Fonseca, G., Vierstraete, A., Vanfleteren, J., Vincx, M., Moens, T., 2008. Disentangling taxonomy within the Rhabditis (Pellioditis) marina (Nematoda, Rhabditidae) species complex using molecular and morphological tools. Zoological Journal of the Linnean Society 152, 1-15. 
Díaz-Asencio, L., Armenteros, M., Díaz-Asencio, M., Fernández-Garcés, R., GómezBatista, M., Alonso-Hernández, C., 2009. Spatial and temporal variations of meiofaunal communities in Cienfuegos Bay, Cuba. Revista de Biología Marina y Oceanografía $44,13-29$

Emerson, B.C., Gillespie, R.G., 2008. Phylogenetic analysis of community assembly and structure over space and time. Trends in Ecology and Evolution 23, 619-630.

Friedrichs, C.T., Wright, L.D., Hepworth, D.A., Kim, S.C., 2000. Bottom-boundarylayer processes associated with fine sediment accumulation in coastal seas and bays. Continental Shelf Research 20, 807-841.

Gobin, J.F., Warwick, R.M., 2006. Geographical variation in species diversity: a comparison of marine polychaetes and nematodes. Journal of Experimental Marine Biology and Ecology 330, 234-244.

Gray, J.S., Elliott, M.S., 2009. Ecology of Marine Sediments. From Science to Management, second ed. Oxford University Press, New York, 225 pp.

Gray, J.S., Wu, R.S., Or, Y.Y., 2002. Effects of hypoxia and organic enrichment on the coastal marine environment. Marine Ecology Progress Series 238, 249-279.

Gyedu-Ababio, T.K., Baird, D., 2006. Response of meiofauna and nematode communities to increased levels of contaminants in a laboratory microcosm experiment. Ecotoxicology and Environmental Safety 63, 443-450.

Hedfi, A., Mahmoudi, E., Boufahja, F., Beyrem, H., Aïssa, P., 2007. Effects of increasing levels of nickel contamination on structure of offshore nematode communities in experimental microcosms. Bulletin of Environmental Contamination and Toxicology 79, 345-349.

Hooper, D.U., Chapin III, F.S., Ewel, J.J., Hector, A., Inchausti, P., Lavorel, S., Lawton, J.H., Lodge, D.M., Loreau, M., Naeem, S., Schmid, B., Setäla, H., Symstad, A.J., Vandermeer, J., Wardle, D.A., 2005. Effects of biodiversity on ecosystem functioning: a consensus of current knowledge. Ecological Monographs 75, 3-35.

Ieno, E.N., Solan, M., Batty, P., Pierce, G.J., 2006. How biodiversity affects ecosystem functioning: roles of infaunal species richness, identity and density in the marine benthos. Marine Ecology Progress Series 311, 263-271.

Kröger, K., Gardner, J.P.A., Rowden, A.A., Wear, R.G., 2006. Long-term effects of a toxic algal bloom on subtidal soft-sediment macroinvertebrate communities in Wellington Harbour, New Zealand. Estuarine, Coastal and Shelf Science 67, 589-604.

Lambshead, P.J.D., 1986. Sub-catastrophic sewage and industrial waste contamination as revealed by marine nematode faunal analysis. Marine Ecology Progress Series 29, 247-260.

Lampadariou, N., Austen, M.C., Robertson, N., Vlachonis, G., 1997. Analysis of meiobenthic community structure in relation to pollution and disturbance in Iraklion Harbour, Greece. Vie Milieu 47, 9-24.

Liu, X.S., Xu, W.Z., Cheung, S.G., Shin, P.K.S., 2008. Subtropical meiobenthic nematode communities in Victoria Harbour, Hong Kong. Marine Pollution Bulletin 56, 1491-1497.

Long, E.R., MacDonald, D.D., Smith, S.L., Calder, F.D., 1995. Incidence of adverse biological effects within ranges of chemical concentrations in marine and estuarine sediments. Environmental Management 19, 81-97.

Loring, D.H., Rantala, R.T.T., 1992. Manual for the geochemical analysis of marine sediments and suspended particulate matter. Earth-Science Review 32, 235-283.

Millward, R.N., Grant, A., 1995. Assessing the impact of copper on nematode communities from a chronically metal-enriched estuary using pollutioninduced community tolerance. Marine Pollution Bulletin 30, 701-706.

Moreno, M., Ferrero, T.J., Gallizia, I., Vezzulli, L., Albertelli, G., Fabiano, M., 2008. An assessment of the spatial heterogeneity of environmental disturbance within an enclosed harbour through the analysis of meiofauna and nematode assemblages. Estuarine, Coastal and Shelf Science 77, 565-576.

Muñoz, A., Douillet, P., Díaz-García, O., Ouillon, S., Fichez, R., 2008. Influencia de la marea, el viento y el aporte fluvial en la circulación de las aguas de la Bahía de Cienfuegos, Cuba. Revista de Investigaciones Marinas 29, 101-112.

Norling, K., Rosenberg, R., Hulth, S., Grémare, A., Bonsdorff, E., 2007. Importance of functional biodiversity and species-specific traits of benthic fauna for ecosystem functions in marine sediment. Marine Ecology Progress Series 332, 11-23.

Pavlyuk, O.N., Trebukhova, Y.A., Shul'kin, V.M., 2003. The structure of a free-living nematode community in Wrangel Bay of the Sea of Japan. Russian Journal of Marine Biology 29, 341-347.

Pérez-García, J.A., Armenteros, M., Díaz-Asencio, L., Díaz-Asencio, M., RuizAbierno, A., Fernández-Garcés, R., Bolaños-Alvárez, Y., Alonso-Hernández, C.,
2009. Spatial distribution of nematode assemblages in Cienfuegos Bay (Caribbean Sea) and their relationships with sedimentary environment. Meiofauna Marina 17, 71-81.

Platt, H.M., Warwick, R.M., 1983. Free-living Marine Nematodes. Part I. British Enoplids. The Linnean Society of London and The Estuarine and Brackish-water Sciences Association, Cambridge, 307 pp.

Platt, H.M., Warwick, R.M., 1988. Free-living Marine Nematodes, Part II. British Chromadorids. The Linnean Society of London and The Estuarine and Brackishwater Sciences Association, Leiden, 502 pp.

Rzeznik-Orignac, J., Fichet, D., Boucher, G., 2003. Spatio-temporal structure of the nematode assemblages of the Brouage mudflat (Marennes Oléron, France). Estuarine, Coastal and Shelf Science 58, 77-88.

Schratzberger, M., Warr, K., Rogers, S.I., 2006. Patterns of nematode populations in the southwestern North Sea and their link to other components of the benthic fauna. Journal of Sea Research 55, 113-127.

Schratzberger, M., Warr, K., Rogers, S.I., 2007. Functional diversity of nematode communities in the southwestern North Sea. Marine Environmental Research $63,368-389$.

Schratzberger, M., Warwick, R.M., 1999. Differential effects of various types of disturbances on the structure of nematode assemblages: an experimental approach. Marine Ecology Progress Series 181, 227-236.

Seisdedo, M., 2006. Variaciones espaciales y temporales en indicadores de la calidad ambiental de las aguas de la Bahía de Cienfuegos, Cuba. Revista de Investigaciones Marinas 27, 159-164.

Seisdedo, M., Muñoz, A., 2004. Influencia de la estacionalidad en el comportamiento fisico-químico de las aguas de la Bahía de Cienfuegos. Revista de Investigaciones Pesqueras 1, 1-7.

Silvester, N.R., Sleigh, M.A., 1985. The forces on microorganisms at surfaces in flowing water. Freshwater Biology 15, 433-448.

Snelgrove, P.V.R., Butman, C.A., 1994. Animal-sediment relationships revisited: cause versus effects. Oceanography and Marine Biology: An Annual Review 32, 111-177.

Soetaert, K., Vincx, M., Wittoeck, J., Tulkens, M., Van Gansbeke, D., 1994. Spatial patterns of Westerschelde meiobenthos. Estuarine, Coastal and Shelf Science 39, 367-388.

Steyaert, M., Moodley, L., Nadong, T., Moens, T., Soetaert, K., Vincx, M., 2007. Responses of intertidal nematodes to short-term anoxic events. Journal of Experimental Marine Biology and Ecology 345, 175-184.

Steyaert, M., Vanaverbeke, J., Vanreusel, A., Barranguet, C., Lucas, C., Vincx, M., 2003. The importance of fine-scale, vertical profiles in characterizing nematode community structure. Estuarine, Coastal and Shelf Science 58, 353-366.

Thistle, D., Lambshead, P.J.D., Sherman, K.M., 1995. Nematode tail-shape groups respond to environmental differences in the deep-sea. Vie et Milieu 45, $107-115$.

Underwood, A.J., 1997. Experiments in Ecology. Their Logical Design and Interpretation Using Analysis of Variance. Cambridge University Press, Cambridge, 504 pp.

Underwood, A.J., Chapman, M.G., Connell, S.D., 2000. Observations in ecology: you can't make progress on processes without understanding the patterns. Journal of Experimental Marine Biology and Ecology 250, 97-115.

Vanaverbeke, J., Vincx, M., 2008. Short-term changes in nematode communities from an abandoned intense sand extraction site on the Kwintebank (Belgian Continental Shelf) two years post-cessation. Marine Environmental Research 66, 240-248.

Vincx, M., 1996. Meiofauna in Marine and Freshwater Sediments. In: Hall, G.S. (Ed.), Methods for the Examination of Organismal Diversity in Soils and Sediments. University Press, Cambridge, pp. 187-195.

Warwick, R.M., Platt, H.M., Somerfield, P.J., 1998. Free-living Marine Nematodes. Part III. Monhysterids. The Linnean Society of London and The Estuarine and Coastal Sciences Association, Shrewsbury, $296 \mathrm{pp}$

Wieser, W., 1953. Die Bezichung swischen Mundhöhlengestalt, Ernährungsweise und Vorkommen bei freilebenden marinen Nematoden. Arkive för Zoologi 4, 439-484.

Zajac, R.N., Whitlatch, R.B., Thrush, S.F., 1998. Recolonization and succession in softsediment infaunal communities: the spatial scale of controlling factors. Hydrobiologia 375/376, 227-240. 